\title{
Establishment and characterization of the gemcitabine-resistant human pancreatic cancer cell line SW1990/gemcitabine
}

\author{
YUE YU $^{1 *}$, FEI DING ${ }^{1,2^{*}}$, MENG GAO $^{1}$, YI FU JIA ${ }^{1}$ and LE REN $^{1}$ \\ ${ }^{1}$ Department of Gastroenterology, Affiliated Provincial Hospital, Anhui Medical University, Hefei, Anhui 230001; \\ ${ }^{2}$ Department of Gastroenterology, Anqing First People's Hospital, Anqing, Anhui 246000, P.R. China
}

Received March 17, 2018; Accepted April 8, 2019

DOI: $10.3892 / \mathrm{ol} .2019 .10627$

\begin{abstract}
Due to its rapid progression, metastasis and resistance to chemotherapy, pancreatic cancer is one of the most malignant tumor types to affect the digestive system. Gemcitabine chemotherapy is typically the first choice of treatment for advanced pancreatic cancer; however, chemoresistance is a major obstacle to successful treatment. In order to elucidate the underlying mechanisms of gemcitabine resistance in pancreatic cancer, the drug-resistant cell line SW1990-gemcitabine (SW1990-GZ) was established using the human pancreatic cancer cell line SW1990. The $\mathrm{IC}_{50}$, resistance index and growth of SW1990 and SW1990-GZ cells were also assessed using 3-(4,5-dimethyl-2-thiazolyl)-2,5-diphenyl-2-H-tetrazolium bromide (MTT) assays. The cellular uptake of gemcitabine in SW1990 and SW1990-GZ was measured using high performance liquid chromatography (HPLC). The protein expression of p53 was also assessed by western blot analysis. The results demonstrated that the $\mathrm{IC}_{50}$ of SW1990 and SW1990-Gz was $0.07 \pm 0.0021$ and $87.5 \pm 3.24 \mu \mathrm{g} / \mathrm{ml}$, respectively, and that the resistance index ratio of SW1990-Gz was 1,250. The growth rate of SW1990-GZ cells was low compared with that of SW1990 cells. The HPLC results indicated that gemcitabine uptake was markedly reduced in SW1990-GZ cells compared with in SW1990 cells at different time points. The protein expression of p53 was significantly higher in GEM-resistant SW1990-GZ cells compared with that in SW1990 cells $(\mathrm{P}<0.01)$. These results suggest that a human gemcitabine-resistant pancreatic cancer cell line was successfully established, with stable and significant drug resistance. The results of the present study suggest that the decreased cellular uptake of gemcitabine may serve an important role in gemcitabine chemoresistance
\end{abstract}

Correspondence to: Professor Yue Yu, Department of Gastroenterology, Affiliated Provincial Hospital, Anhui Medical University, 81 Mei-Shan Road, Hefei, Anhui 230001, P.R. China

E-mail: yuyuemd@163.com

\section{*Contributed equally}

Key words: human pancreatic cancer cell lines, gemcitabine, drug resistance in SW1990-GZ cells; thus, this cell line may be used as an effective in vitro model to improve our understanding of gemcitabine-resistance in pancreatic cancer.

\section{Introduction}

Pancreatic cancer is an aggressive disease with high morbidity and mortality and an overall 5-year survival rate of $<5 \%(1,2)$. The typical prognosis for patients with pancreatic cancer is poor due to rapid disease progression and a lack of effective therapies for the disease in its later stages $(3,4)$. The majority of patients with pancreatic cancer are not eligible for surgery due to diagnosis in the late stage of disease, while the disease also has low sensitivity to radiotherapy (5-7). In addition, chemoresistance is often observed, which greatly reduces the efficacy of chemotherapy (8). Gemcitabine (GEM), which is a first-line drug for the treatment of pancreatic cancer, has been reported to improve the therapeutic efficacy and patient quality of life compared with traditional chemotherapeutic agents (9). However, with the emergence of GEM resistance, the treatment efficacy of GEM in pancreatic cancer is declining (10). Although the mechanisms of GEM resistance in pancreatic cancer have been widely explored, it still remains largely unclear. It is therefore of great importance to construct GEM-resistant pancreatic cancer cell lines in order to further explore the mechanisms of GEM-resistance and develop an effective strategy to overcome drug resistance and improve treatment efficacy.

The P53 gene is an important antioncogene (11). As a nuclear transcription factor, the p53 protein can activate the expression of many target genes, induce DNA damage, and subsequently lead to cell senescence and death (12). A previous study has shown that the $\mathrm{p} 53$ protein not only plays an important role in tumorigenesis, but also participates in the generation of drug resistance of many chemotherapeutic drugs, including GEM (13). Thus, the protein expression of p53 in the GEM-resistant cells are line SW1990-GZ was compared to the primary SW1990 cells in the present study.

In the present study, the GEM-resistant pancreatic cancer cell line SW1990-GZ was established by exposing parental SW1990 cells, which cannot tolerate GEM, to increasing concentrations of GEM. The GEM-resistant cell line SW1990-GZ was established and the characteristics of SW1990 and SW1990-GZ cells, including the protein expression of $\mathrm{p} 53$, were assessed and compared. 


\section{Materials and methods}

Materials. The human pancreatic cancer cell line SW1990 was obtained from the Cell Bank of the Chinese Academy of Sciences (Shanghai, China). MTT and dimethyl sulfoxide (DMSO) were purchased from Sigma-Aldrich (Merck KGaA, Darmstadt, Germany). Also, 2,2-difluorodeoxycytidine (gemcitabine, GEM) was purchased from Eli Lilly Company. Phosphate-buffered saline (PBS), fetal bovine serum (FBS), and RPMI-1640 were obtained from Invitrogen (Thermo Fisher Scientific, Inc., Waltham, MA, USA).

Establishment of the GEM-resistant cell line SW1990-GZ. The GEM-resistant cell line SW1990-GZ was established by exposing SW1990 cells to increasing concentrations $(0.01 \mu \mathrm{g} / \mathrm{ml}$ to $0.5 \mu \mathrm{g} / \mathrm{ml})$ of GEM during the growth phase at $37^{\circ} \mathrm{C}$ for 1 week. SW1990 cells were cultured in RPMI-1640 containing 10\% FBS and different concentrations of GEM.Cell apoptosis was assessed using an MTT assay, and the median lethal dose of SW1990 cells was identified to be $0.07 \mu \mathrm{g} / \mathrm{ml}$. SW1990 cells were the cultured in the RPMI-1640 containing $0.1 \mu \mathrm{g} / \mathrm{ml} \mathrm{GEM}$ at $37^{\circ} \mathrm{C}$ for $48 \mathrm{~h}$, following which the culture and dead cells were replaced with fresh drug-free medium. The remaining cells were cultured under the aforementioned conditions until the logarithmic phase of cell growth was reached. The cells were passaged twice and re-cultured in medium containing GEM at $0.1 \mu \mathrm{g} / \mathrm{ml}$ until they stabilized. The medium was subsequently replaced with culture medium containing $0.4 \mu \mathrm{g} / \mathrm{ml}$ GEM and cultured with a cycle progress as mentioned previously, according to a four-fold increase in the drug concentration. Finally, the cells were cultured in medium containing $400 \mu \mathrm{g} / \mathrm{ml}$ GEM. The remaining viable cells were determined to be stably resistant to high concentrations of GEM. After 10 months, a stable gemcitabine-resistant cell line was successfully acquired and designated as SW1990-GZ. The general induction process is illustrated in Fig. 1.

Morphologic appearance of SW1990 cells and SW1990-GZ cells. SW1990 cells and SW1990-GZ cells were separately cultured in $25 \mathrm{~cm}^{2}$ culture flasks in an atmosphere containing $5 \% \mathrm{CO}_{2}, 37^{\circ} \mathrm{C}$. When cells entered the logarithmic phase, the morphologic appearance of SW1990 cells and SW1990-GZ cells were visualized under an optical microscope (x100 magnification) and kept for further analysis.

MTTassaytoassess GEMsensitivityinSW1990andSW1990-GZ cells. To measure GEM sensitivity, SW1990 and SW1990-GZ cells were seeded in 96-well plates $\left(5.0 \times 10^{3}\right.$ cells/well) and incubated at $37^{\circ} \mathrm{C}$ for $24 \mathrm{~h}$. The medium was then replaced with $100 \mu \mathrm{l}$ medium containing different concentrations of GEM (the concentrations were 400, 200, 100, 50, 25, 12.5, 6.25, $3.125,1.5625$, and $0.7815 \mu \mathrm{g} / \mathrm{ml}$ ) and cultured at $37^{\circ} \mathrm{C}$ for an additional $72 \mathrm{~h}$. Subsequently, $20 \mu \mathrm{l}$ per well of MTT solution $(5 \mathrm{mg} / \mathrm{ml}$; Sigma-Aldrich; Merck KGaA) was added to the cells followed by incubation at $37^{\circ} \mathrm{C}$ for $4 \mathrm{~h}$. Then, $150 \mu \mathrm{l}$ DMSO was substituted for the supernatant, followed by oscillation for $10 \mathrm{~min}$. Absorbance at $490 \mathrm{~nm}$ was detected using a microplate reader (Multiskan MK3; Thermo Labsystems, Santa Rosa, CA, USA). Cell viability $(\%)=\left(\mathrm{OD}_{\text {with drug }}-\mathrm{OD}_{\text {without drug }}\right) /$ $\left(\mathrm{OD}_{\text {control }}-\mathrm{OD}_{\text {without drug }}\right) \times 100$. The resistance coefficient $(\mathrm{R})$ of SW1990-GZ cells was calculated as follows: $\mathrm{R}=\mathrm{IC}_{50}$ [half maximal (50\%) inhibitory concentration $]_{S w 1990-\mathrm{GZ} \text { cells }} / \mathrm{IC}_{50}$ sw1990 cells. Finally, dose-cell survival curves were drawn. Each experiment was repeated at least 3 times.

Growth curves of SW1990 and SW1990-GZ cell lines. To compare the viability of SW1990 and SW1990-GZ cells, cells were seeded in 24-well plates (5.0x10 $0^{3}$ cells/well) and incubated for $24 \mathrm{~h}$ at $37^{\circ} \mathrm{C}$ in an atmosphere containing $5 \% \mathrm{CO}_{2}$. Cells in three apertures were then selected and the number of viable cells was calculated using an MTT assay. This measurement was repeated each day until day 8 and the growth curve was drawn.

Cellular uptake of GEM measured using HPLC. To detect the cellular uptake of GEM, SW1990 and SW1990-GZ cells were seeded in 24-well plates $\left(1.0 \times 10^{5}\right.$ cells/well) and incubated for $24 \mathrm{~h}$. The medium was then replaced with $0.5 \mathrm{ml}$ serum-free medium containing $200 \mu \mathrm{g} / \mathrm{ml}$ GEM and incubated for 2 or $4 \mathrm{~h}$. The cells were washed three times ( 5 min each time) with PBS, lysed, dissolved in methanol and centrifuged at 7,620 x g for $10 \mathrm{~min}$ at $4^{\circ} \mathrm{C}$. Finally, the supernatant was obtained and dried, following which the concentration of GEM in SW1990 and SW1990-GZ cells was determined using a Waters HPLC system (Waters Corporation, Milford, MA, USA) comprising a 1,525 binary pump, 2,487 UV/visible detector, 1,500 column heater and a Symmetry C18 column. The UV/visible detector was set at $405 \mathrm{~nm}$ and linked to Breeze 2 software (Shenzhen, China) for data analysis. HPLC grade ammonium acetate buffer $(0.05 \mathrm{M}, \mathrm{pH} 5.5)$ with methanol at a ratio of 85:15 (v/v) was used as the mobile phase at $30^{\circ} \mathrm{C}$ with a flow rate of $1.0 \mathrm{ml} / \mathrm{min}$. Linear calibration curves for concentrations in the range of $0.1-3.0 \mu \mathrm{g} / \mathrm{ml}$ were constructed by linear regression analysis using the peak areas. The concentration of GEM in the solution was calculated based the standard curve.

Western blot analysis. SW1990 and SW1990-GZ cells were homogenized in a radio immunoprecipitation assay (RIPA) buffer $(50 \mathrm{mM}$ Tris-HCl, pH 7.4, 0.1\% SDS, 1\% NP-40, $0.25 \%$ sodium deoxycholate, $150 \mathrm{mM} \mathrm{NaCl}, 1 \mathrm{mM}$ EDTA, $1 \mathrm{mM}$ EGTA, and $1 \mathrm{mM} \mathrm{Na}_{3} \mathrm{VO}_{4}$ ). Prior to homogenization, a protease inhibitor cocktail (Sigma-Aldrich; Merck KGaA; cat. no. P2714) was added. The protein concentration was measured using the Bradford assay. Proteins $(50 \mu \mathrm{g})$ were separated on $12 \%$ SDS-PAGE gels and were then transferred to PVDF membranes (EMD Millipore, Billerica, MA, USA; cat. no. IPVH00010). Polyvinylidene fluoride membranes were blocked in 5\% bovine serum albumin (Sigma-Aldrich; Merck KGaA; cat. no. A4737) for $1 \mathrm{~h}$ at room temperature and probed with the primary mouse anti-human antibody against p53 (1:1,000; cat. no. 2524; Cell Signaling Technology, Inc., Danvers, MA, USA), and with rabbit anti-human antibody against $\beta$-actin $(1: 1,000$; cat. no. BS1002; Bioworld Technology, Inc., St. Louis Park, MN, USA) as an internal control. These samples were then followed by incubation with horseradish peroxidase conjugated rabbit anti-mouse $(1: 10,000$; cat. no. TA130002; OriGene Technologies, Inc., Beijing, China) and goat anti-rabbit (1:10,000; cat. no. TA130015; OriGene Technologies, Inc., Beijing, China) at $37^{\circ} \mathrm{C}$ for $2 \mathrm{~h}$. The results were visualized using an ECL assay kit (Pierce; Thermo Fisher Scientific, Inc.). The protein levels were analyzed using ImageJ 


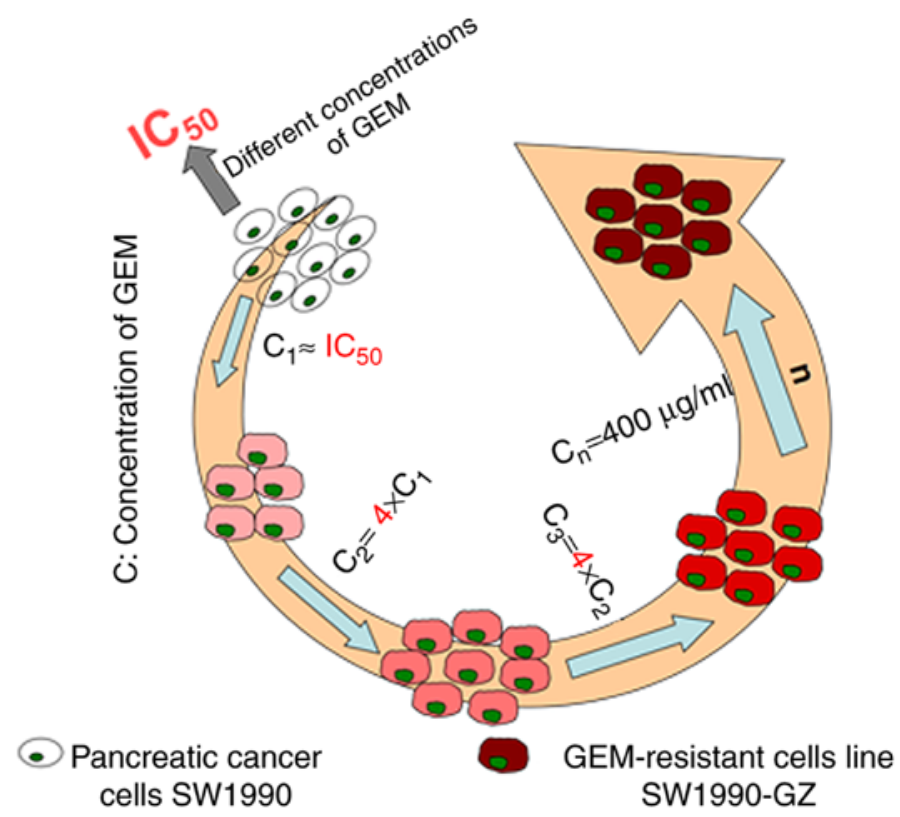

Figure 1. SW1990-GZ cells were established by exposing the pancreatic cancer cell line SW1990 to different concentrations of GEM. GEM, gemcitabine.
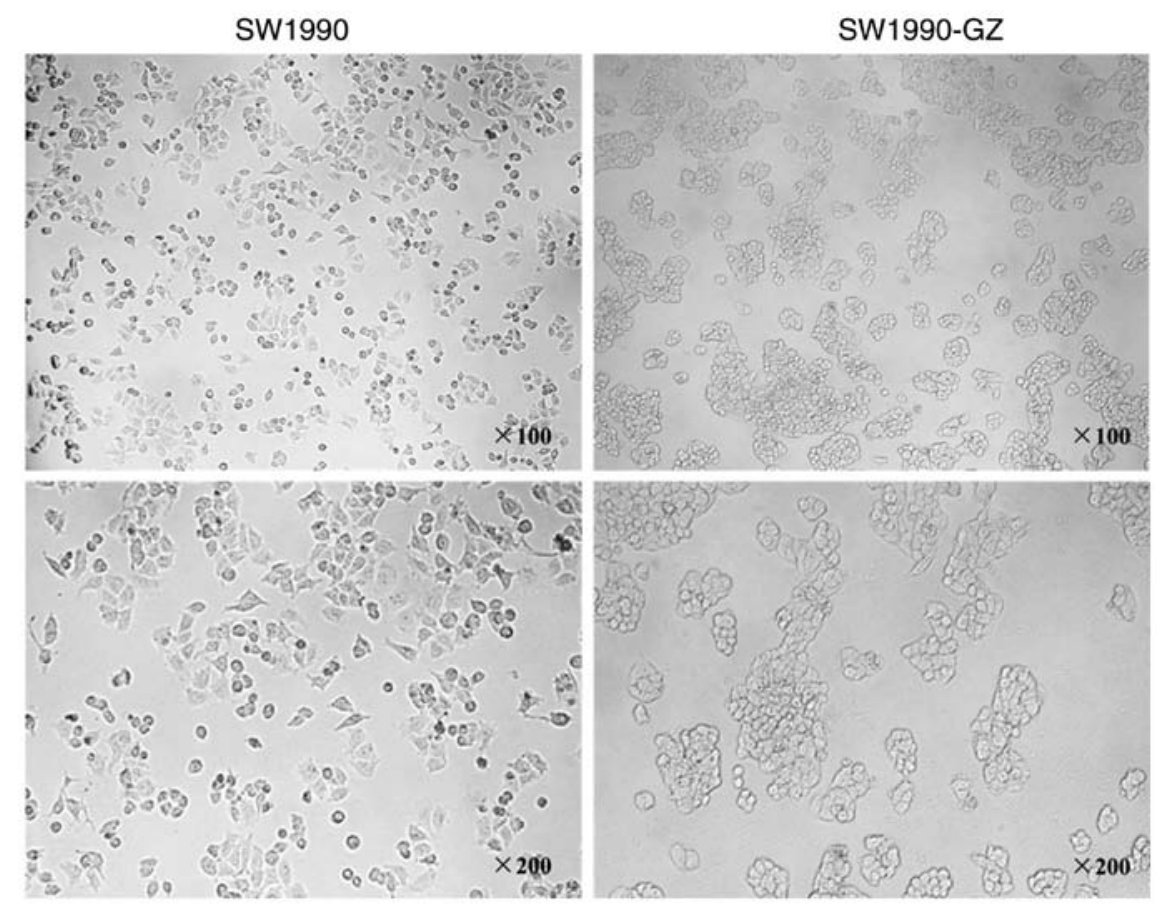

Figure 2. SW1990 and SW1990-GZ cell morphologies were observed under an optical microscope (x100; x200 magnification).

software (v1.8.0; National Institutes of Health, Bethesda, MD, USA) and normalized relative to the internal control.

Statistical analysis. All the statistical analyses were performed using SPSS, (version 12.0.1; SPSS Inc., Chicago, IL, USA). Quantitative data are expressed as the mean \pm standard deviation unless otherwise stated. Statistical analyses of between-group effects on the cytotoxic effects of GEM, the cellular uptake of GEM, and the protein expression of p53 in SW1990-GZ and SW1990 cells were performed using an unpaired Student's t-test. The growth of SW1990-GZ and SW1990 cells were assessed using repeated measures two-way analysis of variance
(ANOVA) with group as between factor and day as within factor followed by a least significant difference (LSD). $\mathrm{P}<0.05$ was considered to indicated a statistically significant difference.

\section{Results}

Morphologic changes in SW1990-GZ cells. SW1990 cells were exposed to increasing concentrations of GEM for 10 months to establish a stable gemcitabine-resistant cell line, SW1990-GZ. Compared with SW1990 cells, the gap junction was increased in SW1990-GZ cells, while more granular substances were also observed (Fig. 2). 


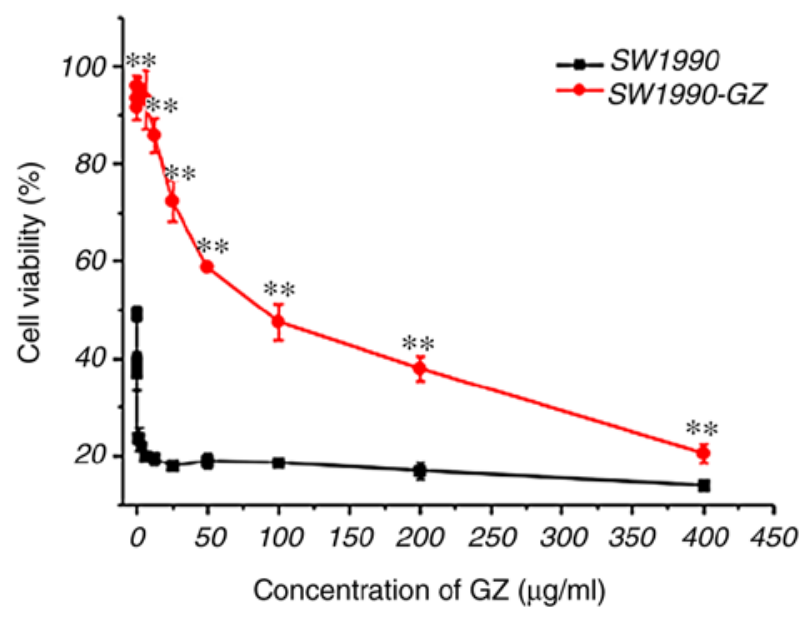

Figure 3. GEM cytotoxicity in SW1990 and SW1990-GZ cells at different concentrations. ${ }^{* *} \mathrm{P}<0.01$ vs. SW1990 cells. GEM, gemcitabine.

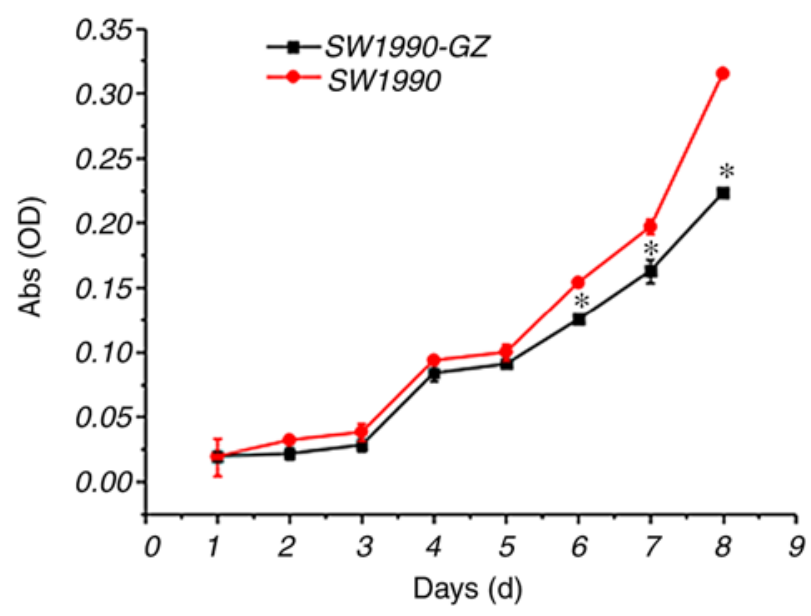

Figure 4. Growth trend of pancreatic SW1990 and SW1990-GZ cells. "P<0.05 vs. SW1990 cells. OD, optical density.

Cytotoxic effects of GEM. To examine the cytotoxicity of GEM, an MTT viability assay was performed for SW1990 and SW1990-GZ cells following treatment with the aforementioned concentrations of GEM. Cell viability was decreased by treatment with GEM in a dose-dependent manner. However, SW1990-GZ cells had a significantly lower sensitivity to GEM compared with SW1990 cells $(\mathrm{P}<0.01)$. These results suggest that SW1990-GZ cells showed obvious GEM resistance (Fig. 3).

Growth of SW1990-GZ and SW1990 cells. As presented in Fig. 4, repeated measures ANOVA revealed that time (number of days cultivated) and group (SW1990 vs. SW1990-GZ) affected the growth of SW1990-GZ and SW1990 cells (time effect: $\mathrm{F}=12.00, \mathrm{P}<0.01$; group effect: $\mathrm{F}=212.17, \mathrm{P}<0.01$; interaction effect: $\mathrm{F}=12.00, \mathrm{P}<0.01)$. The results of $\mathrm{LSD}$ analysis demonstrated that on days 7, 8 and 9, the growth rate of SW1990-GZ cells was low compared with SW1990 cells.

Cellular uptake of GEM in SW1990-GZ and SW1990 cells. Following incubation in culture medium containing

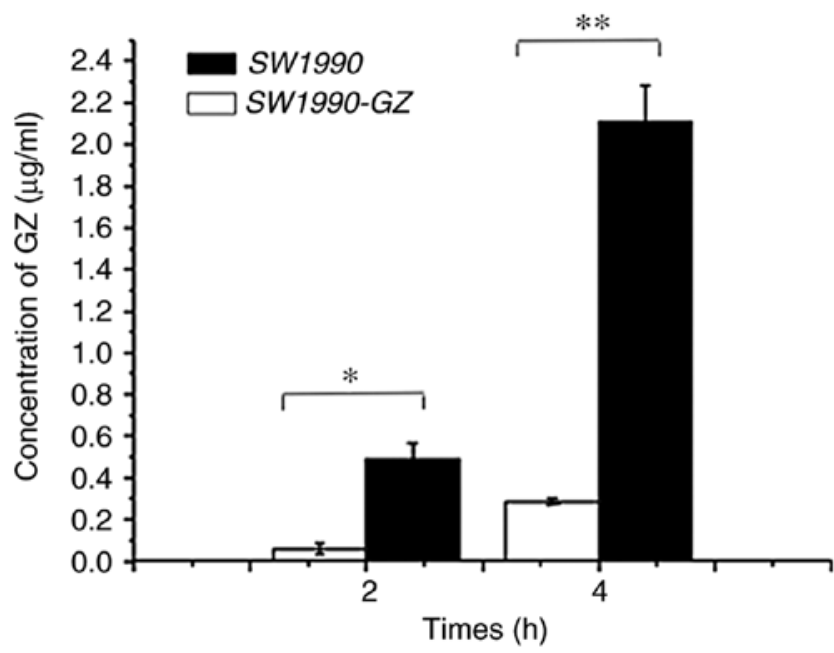

Figure 5. Cellular uptake of GEM in SW1990 cells and SW1990-GZ cells. ${ }^{*} \mathrm{P}<0.05$ and ${ }^{* *} \mathrm{P}<0.01$ vs. SW1990 cells. GEM, gemcitabine.

$200 \mu \mathrm{g} / \mathrm{ml}$ GEM for 2 or $4 \mathrm{~h}$, the uptake efficiency of SW1990 and SW1990-GZ cells was assessed using HPLC. The extraction efficiency of SW1990-GZ and SW1990 cells was found to be 80.26 and $83.12 \%$, respectively. As illustrated in Fig. 5, following incubation with GEM for 2 or $4 \mathrm{~h}$, the amount of intracellular GEM was significantly lower in SW1990-GZ cells compared with in SW1990 cells, suggesting that SW1990-GZ cells had a reduced intake capacity compared with SW1990 cells (At $2 \mathrm{~h}, \mathrm{t}=7.047, \mathrm{P}<0.05$; at $4 \mathrm{~h}, \mathrm{t}=14.81, \mathrm{P}<0.01$ ).

Protein expression of p53 in SW1990-GZ and SW1990 cells. Compared with the SW1990 cells, the protein expression of p53 was significantly increased in the GEM-resistant SW1990-GZ cells (Fig. 6).

\section{Discussion}

There are a number of methods that may be used to generate drug-resistant cancer cell lines, including gene transfection and drug-induction (14-16). In the present study, the GEM-resistant SW1990-GZ cell line was established by exposing pancreatic SW1990 cells to gradually increasing concentrations of GEM for 10 months. During the induction process, the following problems should be addressed; firstly, the $\mathrm{IC}_{50}$ of parental SW1990 cells should be measured and a safe initial concentration of GEM should then be selected. Secondly, prior to increasing the concentration of GEM, the culture medium should be replaced with GEM-free medium to keep cells in a stable growth condition. If the cells are cultured in medium containing different concentrations of GEM, cell viability may be damaged. Thirdly, the concentration of GEM should be increased by an appropriate gradient. Concentration changes that are too large or too small are not conducive to the formation of stably resistant cells. Finally, during the induction process, basic knowledge of cell culture techniques and technologies is critical. The induction of GEM resistance must be performed with great care in order to successfully establish a resistant cell line.

In the present study, cell sensitivity to GEM and GEM uptake capacity were assessed using MTT and HPLC, respectively. The results indicated that the SW1990-GZ cells were 



Figure 6. Protein expression of p53 in SW1990-GZ and SW1990 cells. (A) Western blot. (B) Quantification of the protein expression. ${ }^{* *}$ P $<0.01$ vs. SW1990 cells.

stably resistant to GEM. As such, SW1900-GZ cells may be an ideal cell model for studies aiming to elucidate the mechanisms of drug-resistance in pancreatic cancer. The gradual increase in GEM concentration used in the present study is similar to that observed in chemotherapy. As such, the results of the present study may have clinical applications in cancer therapy.

In the present study, a growth curve was constructed and it was determined that the growth rate of SW1990-GZ cells was significantly lower compared with SW1990 cells. This may be associated with the fact that GEM kills tumor cells primarily via affecting DNA synthesis (17). During the establishment of SW1990-GZ cells, GEM is used to treat the growing cells intermittently, so that the cells in the proliferative phase with active DNA synthesis are inhibited earlier. Continuously carrying out such a screening, the pancreatic cancer cells with poor growth and slow sensitivity to GEM are left behind to form GEM resistant pancreatic cancer cell lines. It has previously been demonstrated that tumor formation and growth are maintained by a heterogeneous group of tumor cells and/or a subset of tumor stem cells (5). One of the important mechanisms contributing to the formation of drug-resistant tumor cells is that stem cells are not killed, while the majority of tumor cells are killed by chemotherapy drugs $(18,19)$. Another study revealed that cancer stem cells grow slowly or stay dormant for long periods (20). In the present study, SW1990-GZ cell growth was much slower compared with the parental SW1990 cell line, which supports previous findings.

The results of the present study also revealed that the GEM uptake capacity was significantly reduced in SW1990-GZ cells compared with SW1990 cells. This suggests that GEM intake was somehow limited in drug-resistant cells or that the drug was rapidly removed from cells after uptake. This eventually leads to a reduced intracellular GEM concentration, resulting in GEM-resistant tumor cells. GEM is a pro-drug which required nucleotides to introduce into cells and exerts a low toxic effect on the cell (21-24). GEM intake decreases if the expression of human equilibrative nucleoside transporter (hENT1) is downregulated, which diminishes the cytotoxicity of GEM $(25,26)$. Previous studies have reported that patients with low hENT1 expression respond poorly to $\operatorname{GEM}(21,27,28)$. Tanaka et al (21) analyzed gene transporter polymorphisms in 149 cases of advanced local pancreatic cancer, and the results demonstrated that the low expression of hENT1 was associated with grade III and IV neutropenia, chemoresistance to GEM
$(\mathrm{P}=0.17)$ and a poor prognosis (progression-free survival of 4.2 vs. 8.3 months). In the present study, the GEM uptake ability of SW1990-GZ cells was significantly lower than SW1990 cells $(\mathrm{P}<0.05)$. This may be a result of low hENT1 expression, and so hENT1 may be an appropriate treatment target for reducing GEM-resistance in pancreatic cancer. In addition, several lines of evidence indicated that abnormal changes in p53 protein levels are considered to be associated with resistance to tumor cells (29). The results demonstrated that the protein expression of p53 was significantly increased in the GEM-resistant SW1990-GZ cells compared with the SW1990 cells (Fig. 1), indicating that increased gemcitabine chemoresistance in SW1990-GZ cells may due to the up-regulated protein expression of $\mathrm{p} 53$, which needs to be confirmed in future studies.

Several studies have indicated that gemcitabine-resistant pancreatic cancer cell strain SW1990-GZ, induced by increasing drug dosage intermittently from SW1990, was extremely stable $(30,31)$. Consistently, the morphological observation and drug resistance testing confirmed the stability of SW1990-GZ cell in the present study. Taken together the above results, we concluded that SW1990-GZ cell may be an ideal tool to investigate the molecular basis of the serious GEM-resistant phenotype of pancreatic cancer cells. However, this conclusion should be verified by repeated experiments.

Several limitations in the present study should be acknowledged. First, since the focus of the present study was on how to establish drug-resistant strains, the mechanisms of drug resistance have not been further examined. For example, due to the fact that GEM introduces DNA damage in cells as detected by $\mathrm{g}-\mathrm{H} 2 \mathrm{AX}$, the amounts of $\mathrm{g}-\mathrm{H} 2 \mathrm{AX}$ between the parental SW1990 cells and SW1990-GZ cells in response to GEM should be checked and compared in subsequent experiments. Secondly, sequencing technology and professional institutions to distinguish the difference between the two cell lines should be conducted. Third, to confirm the hypothesis that GEM resistance of SW1990-GZ cells may be due to their lower uptake of GEM, the expression changes of the transporter genes such as ABC transporters should be investigated. Finally, the present study only carried out drug resistance experiments on SW1990 cells, and not in other pancreatic cancer cell lines.

In summary, the present study successfully established the GEM-resistant SW1990-GZ cell line. By assessing cytotoxicity, cell growth and drug-uptake capacity, the present study confirmed that SW1990-GZ cells are stably resistant to GEM 
and may be used to explore the possible mechanisms of GEM resistance. Further studies may utilize SW1990-GZ cells to further investigate the underlying mechanisms of chemoresistance and develop novel therapeutic targets for pancreatic cancer.

\section{Acknowledgements}

Not applicable.

\section{Funding}

The present study was supported by the External Science and Technology Cooperation Planning Projects of Anhui Province of China (grant no. 1604b0602021).

\section{Availability of data and materials}

All data generated and analyzed during the present study are included in this published article.

\section{Authors' contributions}

YY, FD and MG performed the experiments, contributed to data analysis and wrote the manuscript. YY, FD, YFJ and LR analyzed the data. YY conceptualized the study design and contributed to experimental materials. All authors read and approved the final manuscript.

\section{Ethics approval and consent to participate}

All experiments performed on animals were approved by the Animal Ethics Committee and complied with the Principles of Laboratory Animal Use and Care of Animal Ethics Committee of Anhui Medical University.

\section{Patient consent for publication}

Not applicable.

\section{Competing interests}

The authors declare that they have no competing interests.

\section{References}

1. Siegel RL, Miller KD and Jemal A: Cancer statistics, 2016. CA Cancer J Clin 66: 7-30, 2016.

2. Edwards BK, Noone AM, Mariotto AB, Simard EP, Boscoe FP, Henley SJ, Jemal A, Cho H, Anderson RN, Kohler BA, et al: Annual Report to the Nation on the status of cancer, 1975-2010 featuring prevalence of comorbidity and impact on survival among persons with lung, colorectal, breast, or prostate cancer. Cancer 120: 1290-1314, 2014.

3. Chen YW, Liu JY, Lin ST, Li JM, Huang SH, Chen JY, Wu JY, Kuo CC, Wu CL, Lu YC, et al: Proteomic analysis of gemcitabine-induced drug resistance in pancreatic cancer cells. Mol Biosyst 7: 3065-3074, 2011.

4. Chen W, Zheng R, Baade PD, Zhang S, Zeng H, Bray F, Jemal A, Yu XQ and He J: Cancer statistics in China, 2015. CA Cancer J Clin 66: 115-132, 2016.

5. D'Angelo F, Antolino L, Farcomeni A, Sirimarco D, Kazemi Nava A, De Siena M, Petrucciani N, Nigri G, Valabrega S, Aurello P and Ramacciato G: Neoadjuvant treatment in pancreatic cancer: Evidence-based medicine? A systematic review and meta-analysis. Med Oncol 34: 85, 2017.
6. Rakhra S, Strauss JB, Robertson J, McGinn CJ, Kim T, Huang J, Blake A, Helenowski I, Hayes JP, Mulcahy M and Small W Jr: Hypofractionated conformal radiotherapy with concurrent full-dose gemcitabine versus standard fractionation radiotherapy with concurrent fluorouracil for unresectable pancreatic cancer: A multi-institution experience. J Gastrointest Cancer 47: 196-201, 2016.

7. Żmijewska-Tomczak M, Milecki P, Olek-Hrab K, Hojan K, Golusiński W, Rucińska A and Adamska A: Factors influencing quality of life in patients during radiotherapy for head and neck cancer. Arch Med Sci 10: 1153-1159, 2014.

8. Rajabpour A, Rajaei F and Teimoori-Toolabi L: Molecular alterations contributing to pancreatic cancer chemoresistance. Pancreatology 17: 310-320, 2017.

9. Otake A, Tsuji D, Taku K, Kawasaki Y, Yokoi M, Nakamori H, Osada M, Matsumoto M, Inoue $\mathrm{K}$, Hirai $\mathrm{K}$ and Itoh $\mathrm{K}$ : Chemotherapy-induced neutropenia as a prognostic factor in patients with metastatic pancreatic cancer treated with gemcitabine. Eur J Clin Pharmacol 73: 1033-1039, 2017.

10. Long J, Zhang Y, Yu X, Yang J, LeBrun DG, Chen C, Yao Q and $\mathrm{Li}$ M: Overcoming drug resistance in pancreatic cancer. Expert Opin Ther Targets 15: 817-828, 2011.

11. Soussi T, Dehouche K and Béroud C: p53 website and analysis of p53 gene mutations in human cancer: Forging a link between epidemiology and carcinogenesis. Hum Mutat 15: 105-113, 2000.

12. Coggi G, Bosari S, Roncalli M, Graziani D, Bossi P, Viale G, Buffa R, Ferrero S, Piazza M, Blandamura S, et al: p53 protein accumulation and p53 gene mutation in esophageal carcinoma. A molecular and immunohistochemical study with clinicopathologic correlations. Cancer 79: 425-432, 1997.

13. Dhayat SA, Mardin WA, Seggewiß J, Ströse AJ, Matuszcak C, Hummel R, Senninger N, Mees ST and Haier J: MicroRNA profiling implies new markers of gemcitabine chemoresistance in mutant p53 pancreatic ductal adenocarcinoma. PLoS One 10: e0143755, 2015 .

14. Mezencev R, Matyunina LV, Wagner GT and McDonald JF: Acquired resistance of pancreatic cancer cells to cisplatin is multifactorial with cell context-dependent involvement of resistance genes. Cancer Gene Ther 23: 446-453, 2016.

15. Elaskalani O, Razak NB, Falasca $M$ and Metharom $P$ : Epithelial-mesenchymal transition as a therapeutic target for overcoming chemoresistance in pancreatic cancer. World $\mathbf{J}$ Gastrointest Oncol 9: 37-41, 2017.

16. Azmi AS, Bao B and Sarkar FH: Exosomes in cancer development, metastasis, and drug resistance: A comprehensive review. Cancer Metastasis Rev 32: 623-642, 2013.

17. Ando T, Ichikawa J, Okamoto A, Tasaka K, Nakao A and Hamada Y: Gemcitabine inhibits viability, growth, and metastasis of osteosarcoma cell lines. J Orthop Res 23: 964-969, 2005.

18. Hong SP, Wen J, Bang S, Park S and Song SY: CD44-positive cells are responsible for gemcitabine resistance in pancreatic cancer cells. Int J Cancer 125: 2323-2331, 2009.

19. Qiu H,Fang X, Luo Q and Ouyang G: Cancer stem cells: A potential target for cancer therapy. Cell Mol Life Sci 72: 3411-3424, 2015.

20. Bao Q, Zhao Y, Renner A, Niess H, Seeliger H, Jauch KW and Bruns CJ: Cancer stem cells in pancreatic cancer. Cancers (Basel) 2: 1629-1641, 2010.

21. Tanaka M, Javle M, Dong X, Eng C, Abbruzzese JL and Li D: Gemcitabine metabolic and transporter gene polymorphisms are associated with drug toxicity and efficacy in patients with locally advanced pancreatic cancer. Cancer 116: 5325-5335, 2010.

22. Garcia-Manteiga J, Molina-Arcas M, Casado FJ, Mazo A and Pastor-Anglada M: Nucleoside transporter profiles in human pancreatic cancer cells: Role of hCNT1 in 2',2'-difluorodeoxycytidine-induced cytotoxicity. Clin Cancer Res 9: 5000-5008, 2003.

23. Maréchal R, Mackey JR, Lai R, Demetter P, Peeters M, Polus M, Cass CE, Young J, Salmon I, Devière J and Van Laethem JL: Human equilibrative nucleoside transporter 1 and human concentrative nucleoside transporter 3 predict survival after adjuvant gemcitabine therapy in resected pancreatic adenocarcinoma. Clin Cancer Res 15: 2913-2919, 2009.

24. Nordh S, Ansari D and Andersson R: hENT1 expression is predictive of gemcitabine outcome in pancreatic cancer: A systematic review. World J Gastroenterol 20: 8482-8490, 2014.

25. Hagmann W, Jesnowski R and Löhr JM: Interdependence of gemcitabine treatment, transporter expression, and resistance in human pancreatic carcinoma cells. Neoplasia 12: 740-747, 2010 . 
26. Hesler RA, Huang JJ, Starr MD, Treboschi VM, Bernanke AG, Nixon AB, McCall SJ, White RR and Blobe GC: TGF- $\beta$-induced stromal CYR61 promotes resistance to gemcitabine in pancreatic ductal adenocarcinoma through downregulation of the nucleoside transporters hENT1 and hCNT3. Carcinogenesis 37: 1041-1051, 2016.

27. Sheikh R, Walsh N, Clynes M, O'Connor R and McDermott R: Challenges of drug resistance in the management of pancreatic cancer. Expert Rev Anticancer Ther 10: 1647-1661, 2010.

28. Maréchal R, Bachet JB, Mackey JR, Dalban C, Demetter P, Graham K, Couvelard A, Svrcek M, Bardier-Dupas A, Hammel P, et al: Levels of gemcitabine transport and metabolism proteins predict survival times of patients treated with gemcitabine for pancreatic adenocarcinoma. Gastroenterology 143: 664-674. e6, 2012

29. Cascinu S, Graziano F, Del Ferro E, Staccioli MP, Ligi M, Carnevali A, Muretto P and Catalano G: Expression of p53 protein and resistance to preoperative chemotherapy in locally advanced gastric carcinoma. Cancer 83:1917-1922, 1998.
30. An Y, Yao J, Wei JS, Lu ZP, Cai HH, Dai CC, Qian ZY, Xu ZK and Miao Y: Establish a gemcitabine-resistant pancreatic cancer cell line SW1990/GZ and research the relationship between SW1990/GZ and pancreatic cancer stem cell. Zhonghua Wai Ke Za Zhi 48: 999-1003, 2010 (In Chinese).

31. Niu BZ, Chen G, Li LJ, Wu YD and Zhao YP: Drug resistance and activity changes of thioredoxin reductase in pancreatic cancer cells strain SW1990 induced by gemcitabine. Zhongguo Yi Xue Ke Xue Yuan Xue Bao 27: 606-610, 2005 (In Chinese)

This work is licensed under a Creative Commons Attribution-NonCommercial-NoDerivatives 4.0 International (CC BY-NC-ND 4.0) License. 